\title{
Orbital glomus tumor in an Asian patient
}

\author{
Minwook Chang ${ }^{1}$, Youngseok Lee ${ }^{2}$, Sehyun Baek ${ }^{1}$ and Tae Soo Lee ${ }^{1^{*}}$
}

\begin{abstract}
Background: This report describes a recurrent orbital glomus tumor in an Asian patient.

Case presentation: A healthy 50-year-old Korean man had progressive right exophthalmos and a soft mass on his right lower lid for 6 months. We evaluated the mass using CT and MRI, and performed excisional biopsy and pathologic examination. Pathologically, the mass was a glomus tumor. Although proptosis of the right eye decreased, one month after surgery it increased to almost the same level as before surgery.

Conclusions: This is the first report of an Asian patient with an orbital glomus tumor that demonstrated rapid re-growth after incision without pain or visual problems.
\end{abstract}

Keywords: Orbital glomus tumor, Asian patients, Recur, Rapid growth, Painless

\section{Background}

Glomus tumors are rare, benign neoplasms of the glomus body, a specialized thermoregulatory arteriovenous structure. These tumors most commonly present in the dermis of the digits and palms, [1] and rarely in the orbit. We describe the unique features of a large orbital glomus tumor that developed and re-grew rapidly in an Asian patient.

\section{Case presentation}

Written informed consent was obtained from the patient for the publication of this case report and any accompanying images. A copy of the written consent is available for review by the Editor-in-Chief of this journal. A healthy 50 -year-old Korean man presented with progressive right exophthalmos and a soft mass on his right lower lid that had persisted for 6 months (Figure 1A). He had neither pain nor visual symptoms. On examination, his visual acuity was $20 / 20$ OU. Pupillary, funduscopic, tonometric, and ocular movements were normal. There was $6 \mathrm{~mm}$ of right proptosis (Hertel). Although mild chemosis was found on the right eye, no specific pathologic signs were found. On computed tomography (CT), a well-enhanced mass with dimensions of $38 \times 31 \times 26 \mathrm{~mm}$ was noted in the right intraand extra-conal spaces. The mass appeared to be solid with homogeneous consistency. No bone destruction was

\footnotetext{
* Correspondence: mdjacob@hanmail.net

'Department of Ophthalmology, Korea University College of Medicine, Seoul, Korea

Full list of author information is available at the end of the article
}

evident on the CT scan. A magnetic resonance image (MRI) collected for further evaluation showed a large, lobulated, smooth-margined mass in the lower lateral aspect of the right orbit, measuring $28 \times 33 \times 32 \mathrm{~mm}$ in volume. The largest portion of the mass was located intraconally and focally protruded extraconally in the infero-lateral section. The mass showed a slightly low signal on T1-weighted imaging that was moderately enhanced by contrast study (Figure 1B). The right optic nerve was elevated due to mass effect, and 3/4 of the optic nerve was enclosed within the mass. The clinical diagnosis was a cavernous hemangioma or, less likely, a malignant lymphoma.

To confirm the diagnosis, an incisional biopsy was performed under local anesthesia. A subciliary incision exposed the mass to reveal a smooth, round, highly vascularized tumor. After controlling the extensive bleeding that was encountered, two fragments of the tumor were obtained. The fragments were irregular and multilobulated reddish masses measuring $0.9 \times 0.7 \times 0.6 \mathrm{~cm}$ and $0.6 \times 0.5 \times 0.2 \mathrm{~cm}$. Pathologically, tumor cells were arranged in organoid and sheet-like patterns with intimately associated, capillary-sized blood vessels. The individual tumor cells were round, oval, polyhedral, or fusiform. Nuclei were round or ovoid and centrally placed in pale or slightly eosinophilic cytoplasm. The cell borders were not clearly delineated. Tumor cells were intermingled with thin fascicles of bland spindle cells (Figure 1C) and showed strong cytoplasmic positivity for smooth muscle actin (SMA) (Figure 1D). These findings were consistent with the diagnosis of a glomus tumor. After partial ex- 

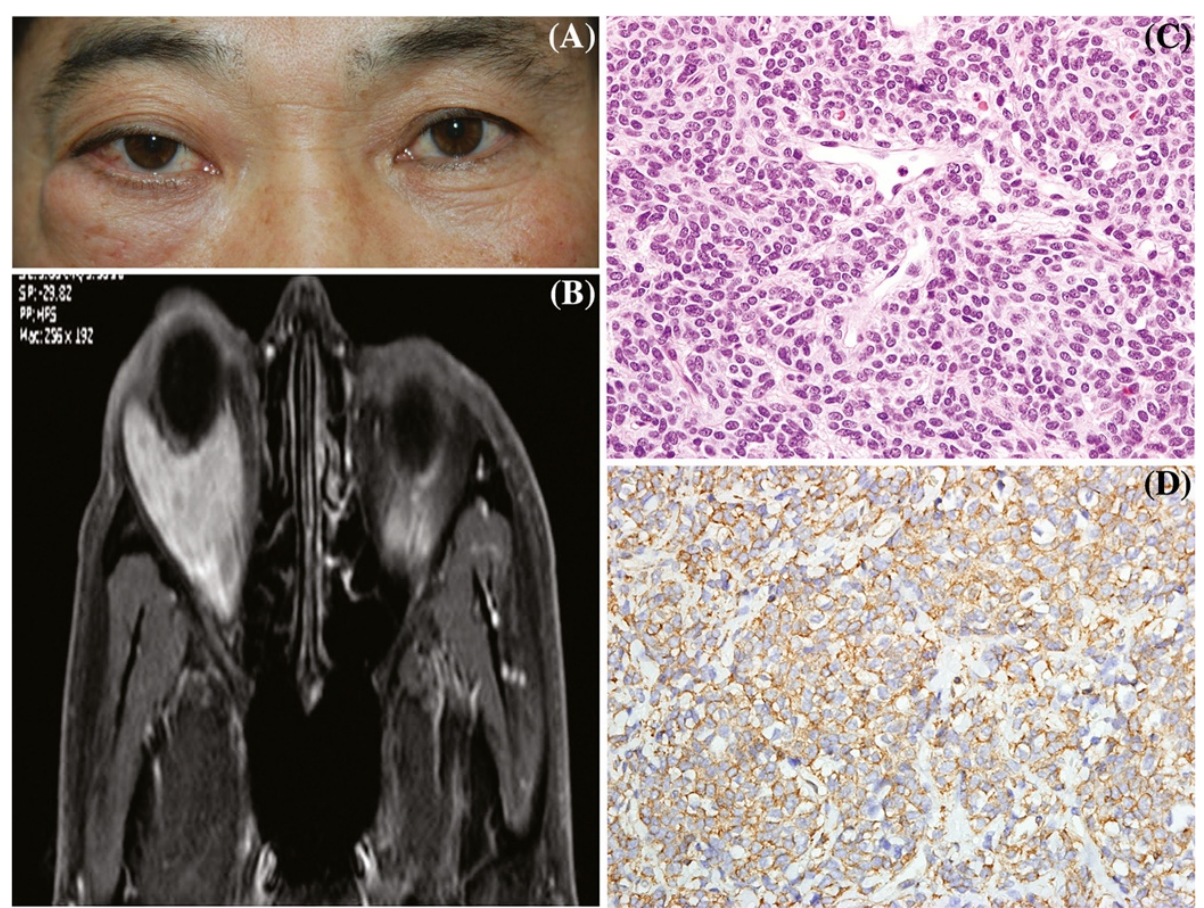

Figure 1 Photographs demonstrating right lower lid swelling and proptosis of the right eye (A). T1-weighted magnetic resonance imaging demonstrated a large, lobulated, smooth-margined mass in the lower lateral aspect of the right orbit, measuring $28 \times 33 \times 32 \mathrm{~mm}$ in volume with a low signal that diffusely enhanced with gadolinium (B). Tumor cells were arranged in organoid and sheet-like patterns, and contained intimately associated capillary-sized blood vessels. Individual tumor cells were round, oval, polyhedral, or fusiform. Nuclei were round or ovoid and centrally placed in pale or slightly eosinophilic cytoplasm. Cell borders were not clearly delineated. Tumor cells were intermingled with thin fascicles of bland spindle cells (hematoxylin-eosin, original magnification $\times 400)(\mathbf{C})$ and showed strong cytoplasmic positivity for smooth muscle actin (SMA) (immunoperoxidase/hematoxylin counterstain, original magnification $\times 400)(D)$

cision, proptosis of the right eye decreased to $4 \mathrm{~mm}$, and lower lid swelling visibly reduced (Figure 2A) However, 1 month after surgery, the proptosis increased to $6 \mathrm{~mm}$, which was almost the same level as before surgery. Lower lid swelling had also increased (Figure 2B). A follow-up CT scan indicated that mass size had increased to the
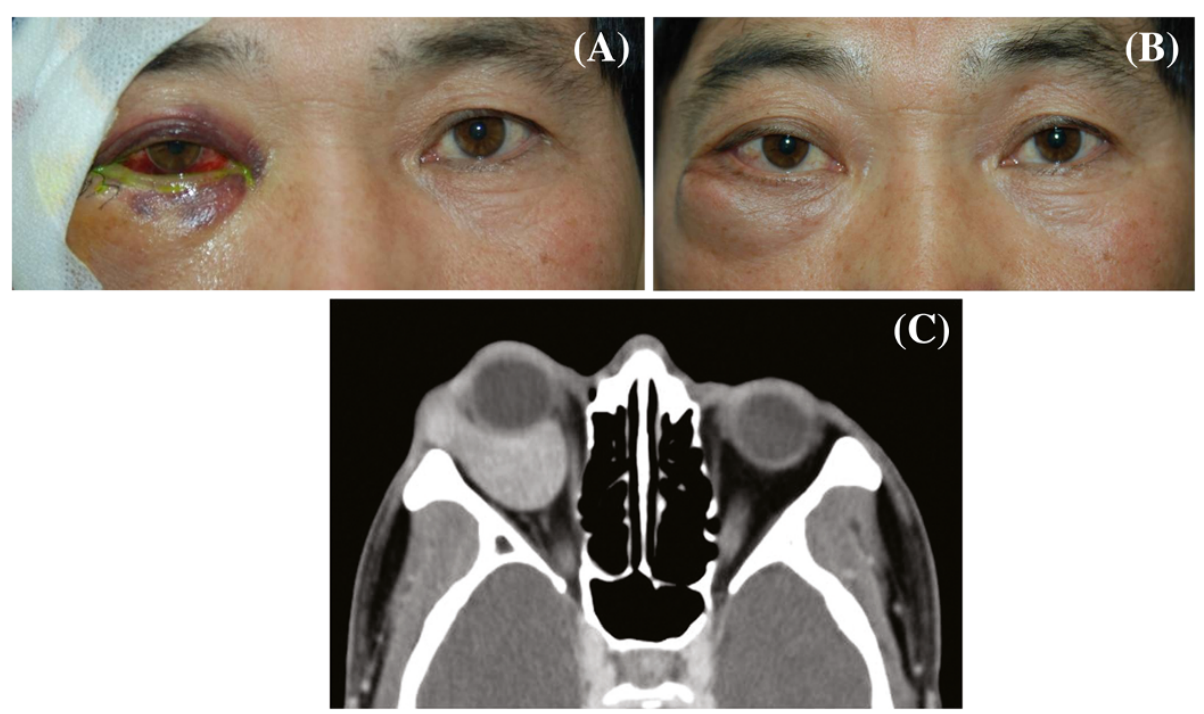

Figure 2 Photographs taken the next day of surgery demonstrating decrease proptosis and lid swelling (A). Photographs taken one month after surgery demonstrating recurred right lower lid swelling and proptosis of the right eye (B). Follow-up computerized tomography demonstrated that mass size was increased to that of the initial mass (C). 
Table 1 Characteristics of previously reported orbital glomus tumors

\begin{tabular}{|c|c|c|c|c|c|c|c|c|c|c|c|}
\hline \multirow{2}{*}{$\begin{array}{l}\text { Report } \\
\text { (year) }\end{array}$} & \multicolumn{2}{|c|}{ Patient } & \multirow[t]{2}{*}{ Onset } & \multirow[t]{2}{*}{ Proptosis } & \multirow[t]{2}{*}{ Pain } & \multirow[t]{2}{*}{ Other signs } & \multirow[t]{2}{*}{ Radiologic findings } & \multirow[t]{2}{*}{ Management } & \multirow[t]{2}{*}{ Gross findings } & \multirow[t]{2}{*}{ Pathology (type) } & \multirow[t]{2}{*}{ Re-growth } \\
\hline & sex & $\overline{\text { age }}$ & & & & & & & & & \\
\hline $\begin{array}{l}\text { Neufeld et al. } \\
\text { (1994) }\end{array}$ & $\mathrm{F}$ & 35 & $1 \mathrm{yr}$ & $4 \mathrm{~mm}$ & none & none & $\begin{array}{l}2.4 \times 1.4 \times 1.6 \mathrm{~cm} \text { Solid } \\
\text { homogenous }(\mathrm{CT})\end{array}$ & cryoextraction & $\begin{array}{l}\text { Fully encapsulates } \\
\text { with a purple-blue color }\end{array}$ & $\begin{array}{l}\text { Glomus cell tumor } \\
\text { proper }\end{array}$ & None \\
\hline $\begin{array}{l}\text { Shields et al. } \\
\text { (2006) }\end{array}$ & M & 17 & $5 y$ rs & none & none & none & - & debulking & $\begin{array}{l}\text { Blue-gray subconjunctival } \\
\text { lesion involving medial } \\
\text { and superior rectus } \\
\text { muscles }\end{array}$ & glomangioma & None \\
\hline $\begin{array}{l}\text { Pribila et al. } \\
\text { (2010) }\end{array}$ & $\mathrm{F}$ & 19 & - & $3.5 \mathrm{~mm}$ & $\begin{array}{l}\text { Painful } \\
\text { burning } \\
\text { sensation }\end{array}$ & $\begin{array}{l}\text { Limited } \\
\text { abduction } \\
\text { and } \\
\text { supraduction }\end{array}$ & $\begin{array}{l}\text { irregular, lobulated, } 2.6 \times 3.5 \times 3.3 \\
\mathrm{~cm} \text { isointense to muscle on } \mathrm{T} 1 \\
\text { weighting imaging, which } \\
\text { was diffusely enhanced with } \\
\text { gadolinium (MRI) }\end{array}$ & exenteration & $\begin{array}{l}\text { Extensive bleeding and } \\
\text { friable }\end{array}$ & $\begin{array}{l}\text { Both glomus cell } \\
\text { tumor proper and } \\
\text { glomangioma }\end{array}$ & None \\
\hline $\begin{array}{l}\text { Ulivieri et al. } \\
\text { (2012) }\end{array}$ & $\mathrm{F}$ & 29 & - & - & Painful & none & $\begin{array}{l}\text { A well-defined circumscribed } \\
\text { mass,displacing the globe and } \\
\text { lateral rectus muscle } \\
\text { inferotemporally }\end{array}$ & $\begin{array}{l}\text { Excision (Kronlein } \\
\text { approach) }\end{array}$ & - & glomangioma & none \\
\hline Our report & M & 50 & 6 mon & $6 \mathrm{~mm}$ & none & none & $\begin{array}{l}\text { smooth marginated, lobulated } \\
2.8 \times 3.3 \times 3.2 \mathrm{~cm} \text {, located intraconally } \\
\text { and extraconally, low signals } \\
\text { on T1 weighting imaging, which } \\
\text { were moderately enhanced with } \\
\text { gadolinium (MRI) }\end{array}$ & Partial excision & $\begin{array}{l}\text { Reddish and pinkish } \\
\text { colored multilobulated } \\
\text { mass }\end{array}$ & $\begin{array}{l}\text { Glomus cell tumor } \\
\text { proper }\end{array}$ & Complete \\
\hline
\end{tabular}


same size as the initial mass prior to excision (Figure 2C). Interestingly, the patient still had no specific symptoms. Visual acuity, visual field, and intra-ocular pressure (IOP) were all within normal ranges. Radiotherapy or debulking surgery were recommended to address the possibility of malignancy, but the patient refused any other treatment. Six months after surgery, the patient was stable. However, his proptosis had increased to $7 \mathrm{~mm}$.

\section{Conclusions}

To our knowledge, only 4 other cases of orbital glomus tumors have been reported, and none of them were in Asian patients [2-5]. We reviewed these previous reports and summarized key characteristics to compare to our case (Table 1). The MRI and gross findings of the tumor presented here are very similar to those of the case reported by Pribila et al. [4]. However, the tumor in our study was histopathologically compatible with a glomus tumor proper, while the tumor in the previous study showed both glomus cell tumor and glomangioma characteristics. The previous patient also had pain at presentation, while ours had no pain or vision symptoms. Unlike in the three previous reports, the tumor in our patient grew very rapidly. In addition, the tumor showed rapid re-growth months after surgical debulking. This fast re-growth may have been an atypical glomus tumor, which is defined by Folpe et al. as a glomus tumor with uncertain malignant potential [6]. Fortunately, our patient had no visual problems, but we recommended continued close observation and further evaluation to rule out the possibility of malignancy. To our knowledge, this is the first report in an Asian patient of an orbital glomus tumor that demonstrated rapid asymptomatic re-growth after surgical debulking.

Competing interests

The authors declare that they have no competing interests.

Authors' contributions

TSL, MC, YL and SB carried out the case report's study, participated in the sequence alignment and drafted the manuscript. All authors read and approved the final manuscript.

\section{Author details}

'Department of Ophthalmology, Korea University College of Medicine, Seoul, Korea. ${ }^{2}$ Department of Pathology, Korea University College of Medicine, Seoul, Korea

Received: 13 June 2012 Accepted: 16 November 2012

Published: 5 December 2012

\section{References}

1. Weiss SW GJ: Perivascular Tumors in Soft Tissue Tumors. In Enzinger and Weiss' soft tissue tumors. 5th edition. Edited by Weiss SW, Goldblum JR, Enzinger FM. Philadelphia, PA:

Mosby Elsevier; 2008:751-767.

2. Neufeld M, Pe'er J, Rosenman E, Lazar M: Intraorbital glomus cell tumor. Am J Ophthalmol 1994, 117(4):539-541.
3. Shields JA, Eagle RC Jr, Shields CL, Marr BP: Orbital-conjunctival glomangiomas involving two ocular rectus muscles. Am J Ophthalmol 2006, 142(3):511-513.

4. Pribila JT, Cornblath WT, Ramocki JM, Marentette $L$, Flint A, Elner VM: Glomus cell tumor of the orbit. Arch Ophthalmol 2010, 128(1):144-146.

5. Ulivieri S, Toninelli S, Giorqio A, Fruschelli M, Miracco C, Oliveri G: Orbital glomangioma. Orbit 2012, 31(4):216-218.

6. Folpe AL, Fanburg-Smith JC, Miettinen M, Weiss SW: Atypical and malignant glomus tumors: analysis of 52 cases, with a proposal for the reclassification of glomus tumors. Am J Surg Pathol 2001, 25(1):1-12.

doi:10.1186/1471-2415-12-62

Cite this article as: Chang et al:: Orbital glomus tumor in an Asian patient. BMC Ophthalmology 2012 12:62.

\section{Submit your next manuscript to BioMed Central and take full advantage of:}

- Convenient online submission

- Thorough peer review

- No space constraints or color figure charges

- Immediate publication on acceptance

- Inclusion in PubMed, CAS, Scopus and Google Scholar

- Research which is freely available for redistribution 